Jurnal Keperawatan Padjadjaran

ISSN 2338-5324 (print)

ISSN 2442-7276 (online)

Online di http://jkp.fkep.unpad.ac.id

DOI : $10.24198 / \mathrm{jkp}$

\title{
Patients Experience and Perception in Preventing Tuberculosis Transmission in Rural Areas: A Qualitative Research
}

\author{
R Endro Sulistyono ${ }^{1}$, Tantut Susanto ${ }^{2}$, Rr Dian Tristiana ${ }^{3}$ \\ ${ }^{1,2}$ Faculty of Nursing, Universitas Jember, Jember, Indonesia \\ ${ }^{3}$ Faculty of Nursing, Universitas Airlangga, Surabaya, Indonesia \\ Corresponding email: radendro1988@unej.ac.id
}

Submitted: 19-12-2019 Accepted: 21-02-2020 Published: 01-04-2020

\begin{abstract}
Tuberculosis (TB) transmission awareness is crucial for TB prevention in the community. However, efforts to prevent TB transmission from TB patients' perspectives, especially in the rural area, are not well documented. This study aimed to explore the efforts made by TB patients in preventing transmission to the community. This research was qualitative research with a phenomenological approach. Participants in this study were 12 people selected by purposive sampling. Data collection was done by in-depth interviews and recorded. Data analysis was carried out by thematic analysis. This study produced seven themes: perception of TB disease, performing alternative treatments, using personal protective equipment, environmental modification, adhering to treatment, limiting interactions with others, and increasing food intake. Knowledge and awareness of TB patients are still an issue in preventing the transmission of TB in the community. Immediate intervention needs to be made regarding increasing knowledge and awareness of TB patients and the supervision of health workers regularly in handling TB disease in the community.
\end{abstract}

Keywords: Community setting, transmission prevention, tuberculosis patients. 


\section{Introduction}

The global tuberculosis report 2019 stated that Indonesia was ranked third (8\%) with the most TB sufferers after India (27\%) and China $(9 \%)$. The total TB Incidence in Indonesia in the last five years was always increased; in 2017, there were 844.000 TB cases, and in 2018 there were 845.000 cases (World Health Organization, 2019). The trend of TB cases in Indonesia has never declined, there are still many cases that have not been reached and detected, even though they were detected and treated but have not been reported (Kementerian Kesehatan RI, 2018). TB is the second leading cause of death in the world. The TB rate in Indonesia is microscopically based on 759 per 100,000 people for ages 15 years and over with a higher number of men than women, and the number in urban areas is higher than in rural areas (World Health Organization, 2019).

Indonesian government has carried out several interventions such as increasing detection with a family approach, resolving under-reporting TB treatment with strengthening Public-Private Mix (PPM), improving TB treatment compliance, Improving the drug-resistant $\mathrm{TB}$ detection system in the form of MDR TB clinics and access to MDR TB therapy, education related to TB in the community and repair of housing, as well as the fulfillment of analysts with increased sensitivity to diagnosis. Indonesia has collaborated with USAID to establish a referral hospital to help improve the number of MDR TB case detection in the past four years and train TB cadres (local health workers) to educate the public about TB control and prevention (USAID, 2017).

Effective collaboration between health services and the community can increase access to TB patients' homes and reduce medical expenses for TB patients and reduce the workload of health workers. The involvement of TB patients in the treatment of TB can also facilitate patient and community empowerment interventions in handling TB. Community empowerment and TB patients can be done by involving patients and communities, health education related to TB related issues, and encouraging changes in healthy living behavior (World Health
Organization, 2008, 2015). Empowering patients and communities require knowledge regarding the rights and responsibilities of each individual, access to information, and the ability to utilize the knowledge and skills needed. Some of the rights of TB patients are attention related to care, appreciation, information, choice, confidence, fairness, organization and security while the obligation of TB patients in the form of information sharing, adherence to treatment, and patient contributions to community health and solidarity (World Health Organization, 2008).

Patients' challenges facing TB transmission prevention in the community might vary within a different context. Therefore, an indepth understanding of the challenges faced by TB patients in TB transmission prevention is crucial to identify potential areas for improvement. This study was thus conducted to explore TB transmission prevention from TB patients' perspectives. This study aims to explore the experience of the efforts of TB patients in preventing TB disease in the community.

\section{Method}

\section{Design}

This research was qualitative research with a phenomenological approach.

\section{Participant}

The participants of this study were TB patients who received treatment with a duration of treatment of six months, lived in a Pandalungan area, were native to the Pandalangan, were at least 18 years old, and could speak Indonesian or Local (Madura). Participant data were obtained from Klakah Public health centers, which were then selected according to inclusion criteria and selected using purposive sampling. The participant has no relationship prior to the researcher. The researcher came to the participant's house to self introduce and explain the purpose of the study and how to collect data and ask for approval to become the participants of the study.

\section{Data Collection Procedure}

Qualitative data was collected through 
R Endro Sulistyono: Patients Experience and Perception in Preventing Tuberculosis Transmision in Rural Areas

in-depth interview methods individually by exploring the experiences of TB patients in an effort to prevent TB transmission in the community using the phenomenology approach. The phenomenology approach aims to describe individual experiences related to a particular phenomenon about how the individual interpreted his experience (Yusuf et al., 2017). The interview process was conducted by ES, which has been experienced in qualitative data collection before and works as a lecturer in community nursing. The interview question begins with the opening question "Tell us about your experience in preventing TB transmission in the environment around you?". Subsequent questions were developed based on participants'responses regarding the questions that were asked to participants. Interviews were conducted in the participant's house, where participants felt comfortable in the interview process. Interviews were conducted using the local language of participants and Indonesian for approximately 30-45 minutes per participant. Participant answers are recorded using a recorder and recorded in the note field during the interview process. The verbatim process of recording into a direct transcript was carried out after the interview was conducted to obtain accurate data. Data collection ends when data saturation occurs.

This study was a part of research tree that explore TB prevention from professional health worker perspectives (Sulistyono et al., 2019) and this study was explore the TB prevention from patient perspectives.

\section{Analysis}

The data analysis process is carried out simultaneously with the process of collecting data. All data were transcribed verbatim and analyzed thematically include identification, coding, analysis, and clustering. The identified themes are displayed with statements from participants with the aim of increasing the wealth and depth of the data found. The participant's quotation is displayed in Italic and followed by participant details.

To ensure rigour, transcripts were read by two researchers (ES and DT). The thematic framework was developed, keeping agreed themes by discussing, negotiating, and agreeing on the content, as well as the development of new themes (or subthemes) where there was disagreement. To ensure the data trust-worthiness, the researcher (ES) was conduct member checking by verifying the transcript to participants and matching it with records and field notes. The study process is discussed with the research supervisor (TS) and the research team.

\section{Ethical Clearance}

The study had obtained ethical approval from the Faculty of Dentistry, Universitas Jember No 114/UN25.8/KEPK/DL/2018 and informed consent were signed by all participants, interview transcripts were coded, and participant details were not collected.

\section{Results}

Table 1 Participants demographic data

\begin{tabular}{|c|c|c|c|c|c|c|}
\hline $\begin{array}{c}\text { No of } \\
\text { Participants }\end{array}$ & Sex & $\begin{array}{c}\text { Age } \\
\text { (years) }\end{array}$ & Job & Living with & Education Level & $\begin{array}{c}\text { Smoking } \\
\text { Habit }\end{array}$ \\
\hline 1 & F & 55 & Housewife & Son & Junior High School & No \\
\hline 2 & F & 24 & Islamic Teacher & Husband & Senior High School & No \\
\hline 3 & M & 39 & Migrant Labor & Wife and Son & Junior High School & No \\
\hline 4 & M & 49 & Farmer & Wife and Daughter & Junior High School & Yes \\
\hline 5 & M & 61 & Pedicab & Grandson & Junior High School & Yes \\
\hline 6 & F & 38 & Housewife & None & Junior High School & No \\
\hline 7 & M & 60 & Farmer & Wife & Junior High School & Yes \\
\hline 8 & M & 21 & Student & Parents & College & Yes \\
\hline 9 & M & 58 & Repairman & Children & Junior High School & No \\
\hline 10 & F & 43 & Grocer & Husband and & Senior High School & No \\
\hline
\end{tabular}

Volume 8 Issue 1 April 2020 
R Endro Sulistyono: Patients Experience and Perception in Preventing Tuberculosis Transmision in Rural Areas

\begin{tabular}{l|c|c|c|c|c|c|}
\hline $\begin{array}{c}\text { No of } \\
\text { Participants }\end{array}$ & Sex & $\begin{array}{c}\text { Age } \\
\text { (years) }\end{array}$ & Job & Living with & Education Level & $\begin{array}{c}\text { Smoking } \\
\text { Habit }\end{array}$ \\
\hline 11 & $\mathrm{M}$ & 55 & Farmer & None & Junior High School & No \\
\hline 12 & $\mathrm{M}$ & 50 & No Job & Wife and Son & Junior High School & Yes \\
\hline
\end{tabular}

Abbreviation:

$\mathrm{F}=$ Female

$\mathrm{M}=$ Male

The sample in this study amounted to 12 participants $(\mathrm{n}=12)$ (Table 1$)$. The age range of participants is $21-65$ years. The total participants in this study were male of 8 participants and four female participants. Almost all participants were educated in junior high school (9 participants). Two participants were educated in high school, and one participant was studying. Two participants were a housewife, one participant as a Moslem reciting teacher; one participant was migrant labor, three participants were farmers, one participant was a pedicab driver, one participant was still in college, the rest were mechanics, sellers and had no job.

\section{Knowledge and Participant Perception of TB disease}

TB is known as lung disease or is known to the public by the name of TBC. Most participants stated that TB was an infectious disease and could be cured. Participants said that the TB disease they suffered could recover if they adhered to treatment. Two participants stated as follows:

“... at first I was worried about coughing up blood, afraid of why, but he said (health professional) this disease could heal..." (Male 39 years)

"... It was already explained by the health workers, I forgot the name that my illness was severe, but this disease can be healed with treatment for about six months ..." (Male 49 years)

Almost all participants said that TB disease is a contagious disease. Some participants stated that TB was transmitted through the airborne, but most interpreted TB transmission with incorrect perceptions, as stated by the following participants:

"I am careful (in behaving) afraid of contagious. I also rarely gather with my wife during treatment, so as not to spread "(Male 49 years)

"I separate my plate from where I eat and drink with my family, so it's not contagious"

(Female, 55 years)

\section{Efforts of TB Patients in Prevention of Transmission of TB}

\section{Performing Alternative Treatment}

Some participants stated that they performing alternative therapy, for example, go to Kiai (Islamic teacher), dukun (Traditional Healer), and drank traditional medicine as an effort to recover while still taking the medication in health services. Participants stated their statements as follows:

"Yeah ... I went to the Kiai (Islam Teacher), $\mathrm{Bu}$ he didn't give me medicine. He told me to drink herbal medicine. What is the herbal medicine name ... (thinking) ... it is white turmeric just the same ... just like gingers" (Female 55 years)

"I drank herbs such as turmeric, temulawak (Curcuma xanthorrhiza Roxb), temu ireng (Curcuma longa L.) is cut into small pieces, the water is boiled. Water with green, water sablukan (rice laundry). Anyway, there are instructions from people; I did it because I wanted to get well. I even do things besides medicine" (Male 49 years)

"I take traditional medicines such as turmeric when coughing" (Female 38 years)

\section{Using personal protective equipment}

Some participants said using personal protective equipment such as masks or closing with their hands when coughing to prevent transmission of TB to others. As stated by participants as follows:

"Even though I always wash until I have something. Ask why I use masks every day. I tell you to get well soon and not spread to others "(Male 39 years)

"Every time I cough, I always close with my hands or tissue or turn back" (Female 24 years)

Another participant said that they were only wearing a mask when they go to the public health center because of fearful that 
health professional workers would be angry because they did not comply with the order to wear a mask. Participants stated the reason for not wearing a mask when outside the health facility because they felt uncomfortable and some participant thought incorrect perceptions of wearing a mask could cause the TB disease that he suffers is hard to be cured as did the participants as follows:

"... I rarely use masks at home. Because when you wear a mask it's hard to breathe. But when I go to the puskesmas (public health center), I use a mask because I must be scolded if I don't obey wearing a mask. I think that when the mask is in the mask, I will breathe again so that the diseases do not heal. If I don't have a mask, I can breathe comfortably ... "(Male 49 years)

"No, I don't wear a mask because it's not good. It feels sticky. Usually, when you check into the puskesmas (public health center), you just use a mask, if you don't use a mask, you can be scolded by the officer. Instead of being scolded, I use it "(Male, 61 years)

\section{Environmental Modification}

\section{Adequate ventilation}

Participants stated that improving ventilation in the home environment is one of the efforts to prevent transmission of TB disease. As the participant's statement is:

"I open the room window so that the sun goes in" (Male 21 years)

"In the past, there was no window, but after being told by Pak Budi (Health Officer) to open it so that sunlight could enter, finally put on the window" (Female 43 years)

"In addition to often opening windows, some tiles in my house are replaced with glass tiles" (Female 24 years)

\section{Sputum Disposal}

Participants said several different ways related to sputum disposal. Sputum disposal is carried out in the toilet, in the trash and wrapped in cloth, and then thrown into the river or burned. As stated by participants as follows:

"I waste my spit (sputum) on the toilet." (Female 55 years) \& (Female 38 years)

"They (sputum) were dumped in the trash, in the river, but they were thrown away at
9-10 a night, I afraid that someone would be in the river, then they would spread. I have to think of others" (Male, 61 years)

"When coughing, the sputum is put on a cloth, clothes that are not worn. After that it is thrown into the river, sometimes burned, sometimes in the toilet "(Male 39 years)

"Usually I waste it sometimes on the ground, then it is evenly spread using sand with my feet" (Female 55 years)

Some participants did not throw sputum in a certain place but are considered throwing out cough sputum even though they know that the disease is an infectious disease. As stated by participants in the following statement:

"Yes, I just do a normal cough without covering it. I throw it wherever I want to throw it" (Male 49 years)

\section{Smoking Behavior}

Participants stated that they quit smoking because they were afraid that the disease would get worse with smoking as said by participants as follows:

"I used to smoke a while, but now that my illness has stopped. Coffee is also rare "(Male 39 years)

Participants said that avoiding cigarette smoke to prevent the disease from getting worse, as told by participants as follows:

"In tahlilan (praying in community), which is usually served by cigarettes, I always choose the position in the front because it feels like to breathe smoke rather tightly" (Male 49 years)

Participants stated that they could not stop their smoking habits. Participants lied to health professional workers when asked about smoking habits such as participant statements as follows:

"When I asked by health professional workers, I said no smoking. It is true when I was asked not to smoke, but after I was at home I smoked in a stall "(Male 61 years)

"When I was at home or asked by my parents to say I didn't smoke, sometimes I kept smoking" (Male 21 years)

\section{Adhering with treatment}

Some participants stated that they tried to take anti-TB drugs on a regular basis despite causing discomfort due to high motivation from themselves to recover. As stated by 
participants as follows:

"The red medicine causes stomach ache if the officers say at the health center, there is a stomach ache, nausea, and so on. This is what pains the stomach. But I still drink medicine; I want to get well" (Female 55 years)

"Initially there was a feeling of boredom, but because I wanted to get well, I drank continuously" (Male 58 years)

Attempts to adhere to taking medication were also carried out because the experience of failure in terms of medication compliance was previously delivered by participants as follows:

"I initially did not like taking medicine, then with Pak Budi (program holder) motivated. It's uncomfortable to take medicine; it feels like there's no change. But he said if it is not treated, it will get worse and more easily spread to the closest people. I have been hospitalized, hot, uncomfortable eating, my appetite dropped. At that time, I did not take medicine. Finally, I have to start treatment since the beginning again "(Male 49 years)

\section{Limit interactions with others}

Some participants said limiting interaction with others to prevent transmission of TB. The interaction limitation is in the form of separating the bedroom from the family and partner and limiting the interaction outside the home with the neighbors. The statement was said by participants as follows:

"I slept alone; my children are in another room. Pak Budi (the holder of the TB program at the Public health center) said that I have to sleep in separate rooms with my family, had to sleep alone for a while during treatment "(Female 55 years)

"I am afraid of contagious care. I also rarely gather with my wife during treatment, so as not to rub off "(Male 49 years)

"While I separate beds with husband" (Female 38 years)

"I often stay at home and rarely gather with neighbors" (Male 50 years)

\section{Increase food intake}

Some participants stated that they increased the number of food portions to prevent worsening of TB disease suffered as presented by participants as follows:
"I Eat three times a day; no restrictions only reduce the oily. I have had no side effects" (Male 49 years)

"Yeah ... yeah, it's not good. After a few days later, it feels good. A day, I eat many times. if there are rujak (traditional food), the main thing is that there are no restrictions that are important to eat" (Male 61 years)

\section{Discussion}

This study produced seven themes: perception of TB disease, performing alternative treatments, using personal protective equipment, environmental modification, adhering to treatment, limiting interactions with others, and increasing food intake.

Most of the participants interpreted TB transmission with incorrect perceptions, even though TB patients in this study conduct care in community health centers and contact with health workers. Incorrect perceptions about TB is an issue that needs to be addressed because it can lead to a false understanding of TB that can hamper efforts to control and prevent TB in the community. Other studies regarding the opinions and false beliefs about TB disease (Buregyeya et al., 2011; Mbuthia et al., 2018) that is regarding the transmission of TB through alternating using tableware from TB sufferers and transmission through smoking behavior.

Some participants performed alternative treatment for the disease. Indonesian community treatment choices, still involve the traditional and the modern, and also individuals who pragmatically decide who to consult, with access and affordability prominent determinants of choice (Viney et al., 2014). this finding can be one of the considerations to include a traditional healer as one of the means of health promotion, especially in TB sufferers to continue to follow the treatment until completion.

The use of masks as an effort to prevent transmission of TB is still not done optimally by TB patients. This finding is consistent with previous study that found that mask use in TB patients tends to be low (Nurhayati et al., 2015). World Health Organization issued a policy that patients need to be educated about the ethics of coughing and respiratory hygiene, 
R Endro Sulistyono: Patients Experience and Perception in Preventing Tuberculosis Transmision in Rural Areas

such as covering the mouth and nose when coughing or sneezing or using covers such as tissues or masks to prevent transmission of TB germs, especially in health care environments. (Jo, 2017). Some participants have carried out the ethics of coughing and using masks to prevent transmission of the disease. However, there are still many participants who do not know the ethics of coughing and are less concerned with the ethics of coughing and the use of masks. Some studies suggest that the implementation of cough ethics is less effective in preventing TB droplet transmission (Zayas et al., 2013) but other studies and WHO state that ethical behavior of coughing needs to be done to reduce TB germs transmission, especially in health care settings and vulnerable groups in the community (Jo, 2017; USAID, 2015).

Air infection control is an effort to control TB disease, which is an essential and often overlooked action. Participants said they made modifications to the environment, so the environment was not humid. Many studies suggest increasing natural ventilation to reduce the transmission of $\mathrm{TB}$ in the home environment (Lygizos et al., 2013; Richardson et al., 2014). The intervention is one of the responses with minimal costs and effective in preventing TB transmission in the environment. Increased ventilation can be done by increasing the number of windows, the ratio of larger windows, as well as windows and doors that are always left open (Lygizos et al., 2013). This is expected to increase the flow of air and sunlight into the room.

The appropriate sputum disposal in TB patients in the home environment is one of the efforts to reduce the transmission of TB in the community. Some literature suggests that health workers should provide education on how to do sputum disposal in TB patients in the home environment that is removing sputum into tissue or paper and burning it or burying it, removing sputum in a pot or a small container that is closed and then burying it (Cheriamane et al., 2017). Proper sputum disposal is an effective way to minimize the spread of TB (Singh et al., 2016). Some participants threw their sputum into the river, and some did not care about sputum discharge management. Health workers need to provide education regarding the safe and correct disposal of phlegm from TB patients. Health workers also need to supervise the residence of $\mathrm{TB}$ patients to improve the correct disposal behavior of phlegm so that it can reduce the transmission of TB in the community. Different perceptions related to the place and method of phlegm disposal need to be facilitated by health workers, for example, the place used for the disposal of phlegm such as cups, cans, places that have been disinfected (Ministry of Health Republic of Indonesia, 2017) or other landfills. Health workers can work with rural cadres in charge of supervision in the home environment.

Most male participants still carry out smoking behavior even though it has been banned by health workers. Other studies suggest that the prevalence of smoking in TB patients is high (Jiménez-Fuentes et al., 2016) where active and passive smokers are independent risk factors for the incidence of TB and increase the progressiveness, severity, and risk of recurrence and mortality of TB disease suffered. The highest smoking behavior is carried out by men (Popovska \& Zakoska, 2014). Health workers can provide education to special groups, especially men, to raise awareness not to smoke. Education also needs to be done on male adolescents to prevent smoking behavior, which can increase the risk of suffering from TB disease. In addition to education, health workers can intervene to change smoking behavior into other habits.

Compliance with TB patients for treatment is an important issue related to TB treatment carried out over a long period of time, which is approximately six months. The long duration of treatment is often the reason for treatment failure in TB patients (Danso et al., 2015). Encouragement from health workers and families is important to maintain TB patient compliance in TB treatment. The experience of failure in TB treatment causes TB patients to have to repeat from the beginning of TB treatment. Increased knowledge of TB patients about the impact that might occur if treatment is not carried out thoroughly needs to be done plus supervision of compliance with taking medication for $\mathrm{TB}$ patients at home.

In this study, there were many participants 
who chose to separate their homes and separate rooms with their spouse or family. Isolation in family and community is a common issue found in TB patients (Tadesse, 2016). Participants even chose to stay alone away from home because they were afraid of infecting their families and even parting with their husbands due to TB disease suffered. The Previous study found that the knowledge and perceptions of families of TB patients related to understanding of TB disease and its treatment are still in a less category (Herawati et al., 2013). Health workers need to provide education about TB disease not only to TB patients but also to family members, so that stigma and isolation do not arise, and social isolation can reduce the quality of life for TB patients. The fulfillment of nutrition is closely related to the treatment of TB. Some studies state that providing nutritional support to TB patients, especially those in poverty, can increase the success of TB treatment in the community (Samuel et al., 2016). The provision of free nutrients that are high in protein needs to be done to support the fulfillment of nutrition for TB patients, especially in rural areas and in the community in the poverty line. TB patients should be educated to do self-management about tuberculosis treatment (Yu et al., 2014).

The benefit of preventing individuals from progressing to active $\mathrm{TB}$, especially persons at high risk of reactivation, is widely accepted (Moonan et al., 2018). The results of this study indicate that TB patients have participated in efforts to prevent the TB transmission into the community, but need support from various parties both from health workers and families and surrounding communities.

\section{Conclusion}

TB patients in rural areas have made efforts to prevent transmission of TB in the community. Some TB patients have done the right way, and some still lack understanding regarding TB disease. Health workers need to educate and increase awareness of TB patients to be involved in preventing the transmission of $\mathrm{TB}$ in the community. The self-management ability of TB patients should be increased. This intervention also needs to be accompanied by supervision in the community with cross-sector collaboration or involving health cadres in supervising compliance and preventing TB transmission behavior in the community.

Funding:This study was funded by Universitas Jember Indonesia.

\section{References}

Buregyeya, E., Kulane, A., Colebunders, R., Wajja, A., Kiguli, J., \& Mayanja, H. (2011). Tuberculosis knowledge, attitudes and health-seeking behaviour in rural Uganda. Int J Tuberc Lung Dis., 15(7), 938-942. https:// doi.org/10.5588/ijtld.10.0211

Cheriamane, D.C., Mohammed, G.J., Verma, B.S., Kandal, I.D., Hari, T., Nian, S.E., \& Asbin, M. (2017). Knowledge of cough hygiene and disposal of sputum in patients with pulmonary tuberculosis. IOSR Journal of Dental and Medical Sciences, 16(2), 82-85. https://doi.org/10.9790/0853-1602028285

Danso, E., Addo, I.Y., \& Ampomah, I.G. (2015). Patients' compliance with tuberculosis medication in Ghana: Evidence from a periurban community. Advances in Public Health. https://doi.org/http://dx.doi. org/10.1155/2015/948487

Herawati, Ruslami, R., \& Yamin, A. (2013). Studi kasus ketidakpatuhan orang kontak serumah terhadap anjuran pemeriksaan tuberkulosis. (Case Study of Non-compliance of Household Contacts with Suggested Tuberculosis Examination). Jurnal Keperawatan Padjadjaran, 1(3), 63-71. https://doi.org/https://doi.org/10.24198/jkp. v1i2.53.g50

Jiménez-Fuentes, M.Á., Rodrigo, T., Altet, M.N., Jiménez-Ruiz, C.A., Casals, M., Penas, A., Mir, I., Reina, S.S., Riesco-Miranda, J.A., \& Caylá, J.A. (2016). Factors associated with smoking among tuberculosis patients in Spain. BMC Infect Dis., 16. https://doi. org/10.1186/s12879-016-1819-1

Jo, K. (2017). Preventing the transmission of tuberculosis in health care settings: 
R Endro Sulistyono: Patients Experience and Perception in Preventing Tuberculosis Transmision in Rural Areas

Administrative control. Tuberc Respir Dis, 80(1), 21-26. https://doi.org/10.4046/ trd.2017.80.1.21.

Kementerian Kesehatan RI. (2018). Rakerkesnas 2018, Kemenkes percepat atasi 3 masalah kesehatan. (2018 Rakernas, Ministry of Health Accelerates Overcoming 3 Health Problems). Kementerian Kesehatan RI.

Lygizos, M., Shenoi, S.V, Brooks, R.P., Bhushan, A., Brust, J.C., Zelterman, D., Deng, Y., Northrup, V., Moll, A.P., \& Friedland, G.H. (2013). Natural ventilation reduces high TB transmission risk in traditional homes in rural KwaZulu-Natal, South Africa. BMC Infect Dis., 13(30). https://doi.org/10.1186/14712334-13-300

Mbuthia, G.W., Olungah, C.O., \& Ondicho, T.G. (2018). Knowledge and perceptions of tuberculosis among patients in a pastoralist community in Kenya: A qualitative study. The Pan African Medical Journal, 30. https:// doi.org/10.11604/pamj.2018.30.287.14836

Ministry of Health Republic of Indonesia. (2017). Tuberculosis (TB). Jakarta: Kementerian Kesehatan RI.

Moonan, P.K., Nair, S.A., Agarwal, R., Chadha, V.K., Dewan, P.K., Gupta, U.D., Ho, C.S., Holtz, T.H., Kumar, A.M., Kumar, N., Kumar, P., Maloney, S.A., Mase, S.R., Oeltmann, J.E., Paramasivan, C.N., Parmar, M.M., Rade, K.K., Ramachandran, R., Rao, R., ..., Khaparde, S.D. (2018). Tuberculosis preventive treatment: The next chapter of tuberculosis elimination in India. $B M J$ Glob Health., 3(5). https://doi.org/:10.1136/ bmjgh-2018-001135

Nurhayati, I., Kurniawan, T., \& Mardiyah, W. (2015). Perilaku pencegahan penularan dan faktor-faktor yang melatarbelakanginya pada pasien tuberculosis multidrugs resistance (TB MDR). Jurnal Keperawatan Padjadjaran, 3(3), 166-175. https://doi.org/https://doi. org/10.24198/jkp.v3i3.118.g109

Popovska, A., \& Zakoska, M. (2014). Smoking habits and degree of nicotine addictions among TB patients. European Respiratory Journal, 44.

Richardson, E.T., Morrow, C.D., Kalil, D.B., Bekker, L.G., \& Wood, R. (2014). Shared air: A renewed focus on ventilation for the prevention of tuberculosis transmission. PLoS One., 9(8). https://doi.org/10.1371/ journal.pone. 0106216

Samuel, B., Volkmann, T., Cornelius, S., Mukhopadhay, S., MejoJose, Mitra, K., Kumar, A.M.V., Oeltmann, J.E., Parija, S., Prabhakaran, A.O., Moonan, P.K., \& Chadha, V.K. (2016). Relationship between nutritional support and tuberculosis treatment outcomes in West Bengal, India. J Tuberc Res., 4(4), 213-219. https://doi.org/10.4236/ jtr.2016.44023

Singh, A., Goyal, V., \& Goel, S. (2016). Sputum collection and disposal perceptions and practices among pulmonary tuberculosis patients from Northern India. J Clin Diagn Res., $\quad 10(11) . \quad$ https://doi.org/10.7860/ JCDR/2016/21673.8978

Sulistyono, R.E., Susanto, T., \& Tristiana, R.D. (2019). Barriers in tuberculosis treatment in rural areas (Tengger, Osing, and Pandalungan) in Indonesia based on public health center professional workers perspectives: A qualitative research. Jurnal Ners, 14(1), 62-68. http://dx.doi. org/10.20473/jn.v14i1.10270

Tadesse, S. (2016). Stigma against tuberculosis patients in Addis Ababa, Ethiopia. PLoS One. https://doi.org/https:// doi.org/10.1371/journal.pone.0152900

USAID. (2017, June). Pengendalian tuberkulosis di Indonesia: Tantangan. (Tuberculosis Control in Indonesia: Challenges). Retrieved August 2, 2019, from https://www.usaid.gov/id/indonesia/ fact-sheets/reducing-multidrug-resistanttuberculosis-indonesia

USAID. (2015). Cover your cough campaign, Myanmar. Control and Prevention of Tuberculosis. Retrieved August 2, 2019, from https://www.usaid.gov/asia-regional/ 
R Endro Sulistyono: Patients Experience and Perception in Preventing Tuberculosis Transmision in Rural Areas

documents/control-and-preventiontuberculosis-project

Viney, K., Johnson, P., Tagaro, M., Fanai, S., Linh, N.N., Kelly, P., Harley, D., \& Sleigh, A. (2014). Traditional healers and the potential for collaboration with the national tuberculosis programme in Vanuatu: Results from a mixed methods study. $B M C$ Public Health, 14(393). https://dx.doi. org/10.1186\%2F1471-2458-14-393

World Health Organization [WHO]. (2008). Implementing the WHO stop TB strategy: A handbook for national tuberculosis control programmes.

World Health Organization [WHO]. (2015). The end TB strategy: Global strategy and targets for tuberculosis prevention, care, and control after 2015. World Health Organization.

World Health Organization [WHO]. (2019). Global tuberculosis report 2019. Retrieved August 18, 2019, from https://www.who.int/ tb/publications/global_report/en/
Yu, S.H., Guo, A.M., \& Zhang, X.J. (2014). Effects of self-management education on quality of life of patients with chronic obstructive pulmonary disease. International Journal of Nursing Sciences, 1(1), 53-57. https://doi.org/10.1016/j.ijnss.2014.02.014

Yusuf, A., Fitryasari, R., Tristiana, R.D., \& Aditya, R.S. (2017). Riset kualtitatif dalam keperawatan. (Qualitative Research in Nursing). Mitra Wacana Media.

Zayas, G., Chiang, M.C., Wong, E., MacDonald, F., \& Lange, C.F. (2013). Effectiveness of cough etiquette maneuvers in disrupting the chain of transmission of infectious respiratory diseases. $B M C$ Public Health, 13(811). https://doi. org/10.1186/1471-2458-13-811 